ISSN: 2302-8556

\title{
Pengaruh Penerapan Total Quality Management, Komitmen Organisasi pada Kinerja Manajerial dengan Reward sebagai Variabel Moderasi
}

\author{
A.A Sagung Istri Devi Parwitasari ${ }^{1}$ \\ I Wayan Pradnyantha Wirasedana ${ }^{2}$
}

\author{
${ }^{1}$ Fakultas Ekonomi dan Bisnis Universitas Udayana (Unud), Bali, Indonesia \\ email: deviparwitasari@yahoo.co.id / Telp: 081999915704 \\ ${ }^{2}$ Fakultas Ekonomi dan Bisnis Universitas Udayana (Unud), Bali, Indonesia
}

\begin{abstract}
ABSTRAK
Kinerja manajerial merupakan salah satu tolak ukur keberhasilan sebuah perusahaan. Kinerja manajerial merupakan faktor penting dalam perusahaan, karena dengan meningkatnya kinerja manajerial diharapkan akan dapat meningkatkan kinerja perusahaan. Penerapan sistem reward di dalam perusahaan akan meningkatkan kualitas kerja manager dalam perusahaan. Adapun tujuan dari penelitian ini adalah untuk mengetahui pengaruh total quality management (TQM), komitmen organisasi pada kinerja manajerial yang dimoderasi oleh sistem reward. Penelitian dilakukan pada 16 rumah sakit di Kota Denpasar. Responden yang digunakan sebanyak 55 orang kepala divisi yang dipilih menggunakan teknik purposive sampling. Metode pengumpulan data yaitu metode survei dengan menggunakan kuesioner. Teknik analisis yang digunakan adalah Moderated Regression Analysis (MRA). Hasil penelitiamenyatakan bahwa variabel total quality management dan komitmen organisasi berpengaruh positif terhadap kinerja manajerial, sedangkan variabel sistem reward memperkuat pengaruh total quality management dan komitmen organisasi pada kinerja manajerial.
\end{abstract}

Kata kunci: total quality management, komitmen organisasi , sistem reward, kinerja manajerial.

\begin{abstract}
Managerial performance becomes one of the benchmarks of a company's success. Managerial performance is an important factor in the company. The implementation of the reward system within the company will improve the quality of the manager's work within the company. The purpose of this study is to determine the effect of total quality management (TQM), organizational commitment to managerial performance moderated by the reward system. This study was conducted at 16 hospitals in Denpasar City. The number of respondents used are 55 heads of divisions which is selected using purposive sampling technique. Data collection methods were conducted by survey using questionnaire. Data analysis technique used is Moderated Regression Analysis (MRA). The final result of the study stated that the total quality management and organizational commitment have positive effect on the managerial performance, while the reward system variable strengthens the influence of total quality management and organizational commitment on managerial performance.

Keywords: total quality management, organizational commitment, reward system, managerial performance.
\end{abstract}




\section{PENDAHULUAN}

Dewasa ini, perkembangan pada bidang ilmu pengetahuan dan pada bidang teknologi berkembang semakin pesat, dengan adanya perkembangan ini mengakibatkan semua perusahaan termasuk rumah sakit bersaing untuk menunjukkan serta meningkatkan kinerja yang dimiliki. Situasi seperti ini menuntut perusahaan untuk berorientasi pada fungsi pelayanan yang efektif dan efisien, hal ini mengakibatkan perusahaan harus meningkatkan kemampuan di bidang operasional maupun bidang manajerial (Sigilipu, 2013). Meningkatkan kinerja dilakukan dengan segala upaya seperti meningkatkan sumber daya serta keunggulan kompetitif yang telah dimiliki agar bisa bersaing dengan perusahaan lainnya. Kinerja menjadi salah satu perhatian dalam sebuah organisasi watau perusahaan. Kinerja merupakan suatu keadaan yang harus diketahui dan diinformasikan kepada pihak-pihak dalam suatu organisasi, yang bertujuan untuk mengetahui tingkat pencapaian hasil suatu perusahaan dan kemudian juga dihubungkan dengan visi yang diusung perusahaan dan juga mengetahui dampak positif dan negatif dari suatu kebijakan operasional perusahaan, jadi kinerja adalah alat manajemen untuk menilai dan melihat perkembangan perusahaan yang dicapai di dalam jangka waktu tertentu (Dewi, 2013).

Kinerja manajerial merupakan kinerja anggota organisasi manajerial, antara lain: perencanaan, investigasi, koordinasi, evaluasi, supervisi, pengaturan staff, negosiasi dan representasi (Nasution, 2005:10). Kinerja manajerial sangat 
dibutuhkan dalam organisasi karena jika kinerja manajerial terlaksana dengan maksimal diharapkan akan membawa keberhasilan perusahaan yang dipimpinnya karena sebagian besar perusahaan diukur dari prestasi dan tentu saja bagaimana kinerja manajerialnya. Pengertian kinerja manajerial menurut Stoner (1996:9) adalah ukuran seberapa efektif dan efisien seorang manajer, seberapa baik dia menetapkan dan mencapai tujuan organisasi. Strategi manajerial tidak hanya dalam hal biaya, namun dapat berupa meningkatkan kualitas produk/jasanya. Alat bantu yang dipakai manajer untuk melaksanakan kinerjanya adalah just in time dan Total Quality Management (TQM). TQM mempunyai kelebihan daripada just in time karena TQM dapat dipraktekkan pada perusahaan jasa, sedangkan just in time hanya di perusahaan manufaktur.

Penerapan total quality management adalah hal yang sangat tepat agar bisa memperbaiki atau meningkatkan kempampuan seluruh elemen-elemen yang ada di dalam organisasi secara berkelanjutan. TQM adalah suatu pendekatan dalam menjalankan bisnis yang mencoba untuk memaksimalkan daya saing dari perusahaan melalui fokus pada kepuasan konsumen, keterlibatan seluruh karyawan dan perbaikan secara terus menerus atas kualitas produk atau jasa serta dengan memperhatikan pengaruh eksternal maupun internal perusahaan (Tjiptono dan Diana, 2001:328).

Selain adanya penerapan Total Quality Management, kinerja para manajer akan meningkat ketika para manajer mempunyai komitmen organisasi yang kuat (Aristiani, 2017). Komitmen organisasi yang kuat dalam diri individu akan menyebabkan inividu berusaha keras mencapai tujuan organisasi sesuai dengan 
A.A Sagung Istri Devi Parwitasari dan I Wayan Pradnyantha Wirasedana. Pengaruh...

tujuan dan kepentingan organisasi atas nama organisasi akan meningkatkan kinerja manajerial (Nouri dan Parker, 1998). Komitmen organisasi yang tinggi akan meningkatkan kinerja yang tinggi pula (Randal, 1990).

Ketidakkonsistenan hasil antara penelitian-penelitian sebelumnya menjadi motivasi peneliti untuk melakukan penelitian kembali mengenai pengaruh TQM dan komitmen organisasi pada kinerja manajerial dengan reward sebagai variabel moderasi. Bukti penelitian sebelumnya menjelaskan hasil penelitian yang bervariasi dan tidak konsisten seperti pada penelitian yang dilakukan oleh Supratiningrum (2003), Narsa (2003), Mardiyah (2005) memperoleh hasil TQM berpengaruh positif terhadap kinerja manajerial, hal tersebut berbeda dengan penelitian oleh Rian (2012), Cynthia (2013) Nastiti (2013) yang memperoleh hasil TQM dan komitmen organisasi berpengaruh negatif terhadap kinerja manajerial. Adanya inkonsistensi maka dari itu perlu adanya pendekatan kontijensi yang mampu bertindak sebagai variabel moderasi maka ditambahkanlah variabel sistem reward, selain itu menurut Amstrong dan Baron (1998) salah satu faktor yang mempengaruhi kinerja manajerial adalah faktor tim atau kelompok dimana didalamnya termasuk fasilitas yang disediakan oleh organisasi yaitu sistem reward.

Sistem reward adalah salah satu dari strategi manajemen untuk menciptakan keselarasan antar karyawan dalam hal ini manajer untuk mencapai tujuan dan sasaran yang telah ditetapkan perusahaan (Walker, 1992), jadi ketika sebuah perusahaan sudah menerapkan TQM dengan baik dan ditambah dengan menerapkan system reward yang baik pada tenaga kerjanya maka dengan itu kinerja akan semakin bagus atau dengan kata lain semakin tinggi reward yang 
ISSN: 2302-8556

diberikan maka kinerja akan semakin baik. Hal tersebut didukung oleh penelitian yang dilakukan oleh Narsa (2013) yang menyatakan bahwa para manajer akan lebih termotivasi untuk meningkatkan kinerja manajerial mereka, jika mereka menerima pengukuran kinerja yang tinggi dalam bentuk reward yang memadai. Sistem reward juga berpengaruh pada komitmen organisasi, semakin bagus sistem reward dalam suatu perusahaan maka semakin tinggi pula komitmen sesorang terhadap organisasinya (Wulandari, 2016).

Sistem reward atau kompensasi mampu memberikan peningkatan pada kinerja, namun juga dapat menurunkan kinerja jika karyawan merasa reward yang diperoleh tidak sebanding dengan hasil kerjanya dan pada akhirnya tujuan organisasi untuk meningkatkan kinerjanya tidak tercapai, dan dengan reward yang tidak sesuai otomatis komitmen organisasi juga rendah karena perusahaan dianggap tidak adil dalam memperlakukan mereka. Reward yang diterima para manajer bebentuk finansial seperti gaji, bonus, asuransi karyawan, bantuan sosial, tunjangan hari raya maupun bentuk non finansial seperti promosi kenaikan pangkat dan lainlain (Muljani, 2002).

Menurut Tati Suhartati Joesron, (2003:1), definisi rumah sakit adalah badan usaha yang berbentuk nirlaba (Non Profit Oriented), tapi dalam proses usahanya tidak terlepas dari persaingan, untuk itu memerlukan suatu organisasi yang kuat dengan sumber daya pendukung yang berkualitas. Pada era ini dalam rumah sakit terjadi pergeseran paradigma dari organisasi orientasi non profit menjadi profit, sehingga pengelolaan rumah sakit tidak hanya sebagai unit sosial semata, tapi juga menjadi unit sosio-ekonomi dan tetap mempunyai tanggung jawab sosial tetapi 
A.A Sagung Istri Devi Parwitasari dan I Wayan Pradnyantha Wirasedana. Pengaruh...

dalam pengelolaan keuangannya menerapkan prinsip-prinsip ekonomi (Helmy, 2015). Perubahan paradigma ini membuat rumah sakit dituntut mempertanggung jawabkan kinerjanya secara total, baik kinerja keuagan maupun kinerja manajerial dengan peningkatan mutu yang terus menerus.

Berdasarkan data yang diperoleh dari website departemen kesehatan pertumbuhan rumah sakit di Indonesia dalam satu tahun (2015-2016) ada sebanyak 133 rumah sakit baru atau mengalami pertumbuhan sebesar 5,3\%, kemudian menurut direktorat pelayanan kesehatan tantangan yang harus dihadap rumah sakit di Indonesia umumnya adalah kapasitas manajemen yang tidak merata dan belum menerapkan manajemen berbasis kinerja. Menurut Tjiptono dan Diana (2001:64) adanya peningkatan kualitas dalam aspek produk dan jasa serta aspek manajemen bisa membawa organisasi mampu bertahan di lingkungan bisnis global. Diterapkanya total quality management diharapkan bisa mengatasi permasalahan ini, dan komitmen organisasi juga diperlukan dalam kinerja manajerial karena jika seorang karyawan memiliki komitmen organisasi yang tinggi akan menyebakan karyawan setia serta memiliki loyalitas yang tinggi terhadap organisasinya.

Penelitian ini mengambil starting point dari penelitian yang dilakukan oleh Intan (2013). Variabel-varibel yang dipergunakan dalam penelitian ini adalah penerapan total quality management, komitmen organisasi, dan sistem penghargaan (reward). Perbedaan penlitian ini dengan penelitian sebelumnya terletak pada variabel yang digunakan dan juga tempat penelitian. Pada penelitian ini ada penambahan variabel komitmen organisasi dan penghapusan variabel sistem pengukuran kinerja, kemudian dalam penelitian ini juga terjadi perubahan pada 
ISSN: 2302-8556

variabel reward yang sebelumnya variabel bebas menjadi variabel moderating. Pada tempat penelitian juga terjadi perubahan pada tempat penelitian sebelumnya dilakukan di Hotel di kota Padang dan Bukittinggi, di dalam penelitian ini penulis meneliti di Rumah Sakit Umum di Kota Denpasar.

Tujuan dari penelitian ini yaitu: 1) Untuk mengetahui pengaruh penerapan total quality management pada kinerja manajerial di Rumah Sakit se kotaDenpasar; 2) Untuk mengetahui pengaruh komitmen organisasi pada kinerja manajerial di Rumah Sakit se Kota-Denpasar; 3) Untuk mengetahui sistem reward dapat memoderasi pengaruh penerapan total quality management pada kinerja manajerial di Rumah Sakit se Kota-Denpasar; 4) Untuk mengetahui sistem reward dapat memoderasi pengaruh komitmen organisasi pada kinerja manajerial di Rumah Sakit se Kota-Denpasar.

Hasil dari penelitian ini diharapkan dapat memberikan kontribusi tambahan ilmu pengetahuan dan wawasan kepada akademisi khususnya terkait ilmu akuntansi manajemen, sehingga dapat mengetahui pentingnya penerapan total quality management, komitmen organisasi dan sistem reward pada kinerja manajerial pada organisasi maupun pada perusahaan. Selain itu, penelitian ini juga diharapkan menjadi acuan atau pembanding untuk penelitian selanjutnya dengan topik sejenis.

Pendekatan kontinjensi digunakan sebagai teori yang mendasari penelitian ini. Sistem akuntansi manajemen merupakan suatu pendekatan kontinjensi dari faktor kondisional yang digunakan dalam penelitian sebagai variabel yang memoderasi suatu hubungan. Teori kontinjensi dalam metode penelitian 
A.A Sagung Istri Devi Parwitasari dan I Wayan Pradnyantha Wirasedana. Pengaruh...

mengargumenkan bahwa efektivitas desain sistem akuntansi manajemen tergantung eksistensi perpaduan antar organisasi dengan lingkungannya. Sistem akuntansi manajemen dikatakan variabel pemoderasi yang mempengaruhi hasil hubungan antara penerapan TQM, komitmen organisasi terhadap kinerja manajerial. Sistem akuntansi manajemen dapat digunakan sebagai mekanisme untuk memotivasi dan mempengaruhi perilaku karyawan dalam berbagai cara yang akan memaksimalkan kesejahteraan organisasi dan karyawan, sebagai alat kontrol organisasi dan alat yang efektif menyediakan informasi yang bermanfaat guna memprediksi konskuensi yang mungkin terjadi atas berbagai aktivitas yang dilakukan. Salah satu komponen penting sistem akuntansi manajemen yang akan dipergunakan dalam penelitian ini adalah sistem reward. Sistem reward dalam penelitian digunakan sebagai variabel yang memoderasi suatu hubungan dan sebagai faktor kontinjensi dalam upaya peningkatan kinerja manajerial (Dahar, 2012).

TQM adalah suatu pendekatan manajemen pada organisasi, yang berfokus pada kualitas serta didasari pada partisipasi sumber daya manusia yang ada di dalam organisasi itu. TQM merupakan suatu sistem untuk perbaikan kinerja yang dapat dilakukan secara terus menerus dengan tujuan untuk dapat menciptakan kinerja manajerial yang lebih baik. Dengan adanya TQM, diharapkan organisasi dapat melakukan perbaikan secara terus menerus dan tetap menjaga kekonsistenannya dalam melayani konsumen sehingga diharapkan dapat memberikan dampak positif bagi organisasi melalui perbaikan-perbaikan kinerja yang telah diterapkan (Angelina, 2012). 
ISSN: 2302-8556

Salah satu tujuan perusahaan adalah tercapainya kepuasan pelanggan yang ditandai dengan berkurangnya keluhan dari para pelanggan sehingga menunjukkan adanya peningkatan kinerja perusahaan (Putro, 2010). Menurut penelitian sebelumnya yang dilakukan oleh Suprantiningrum (2002), Narsa dan Yuniawati (2003), serta Bekka (2007), memperoleh hasil TQM berpengaruh terhadap kinerja manajerial. Sedangkan penelitian oleh Angelina (2012) dan Kumentas (2013) memperoleh hasil yang berbeda yaitu TQM tidak berpengaruh terhadap kinerja manajerial. Berdasarkan teori dan penelitian sebelumnya, maka dapat dirumuskan hipotesis pertama yakni sebagai berikut :

$\mathrm{H}_{1}$ : Penerapan total quality management berpengaruh positif pada kinerja manajerial.

Komitmen organisasi adalah suatu tingkat keyakinan sejauh mana seseorang karyawan memihak pada suatu organisasi tertentu yang tujuanya berniat memelihara keanggotaan dalam organisasi itu. Komitmen seseorang terhadap organisasinya menjadi isu penting dalam dunia kerja. Beberapa organisasi memasukkan unsur komitmen sebagai salah satu syarat untuk memegang suatu jabatan dalam kualifikasi lowongan pekerjaan. Tinggi atau rendahnya komitmen organisasi akan menentukan kinerja yang akan dicapai oleh organisasi, komitmen bisa tercapai apabila inividu dalam organisasi menjalankan hak dan kewajiban sesuai dengan tugasnya masing-masing dalam organisasi. Komitmen yang tinggi akan membuat inividu dalam organisasi berusaha keras meningkatkan kinerja organisasi. 
A.A Sagung Istri Devi Parwitasari dan I Wayan Pradnyantha Wirasedana. Pengaruh...

Penelitian sebelumnya oleh Endang dan Muhhamad (2015), Sumarno (2005) menunjukkan bahwa variabel komitmen organisasi berpengaruh signifikan positif terhadap kinerja manajerial. Sedangkan penelitian yang dilakukan oleh Anggela (2005) dan Rafika (2010) menunjukkan bahwa variabel komitmen organisasi tidak berpengaruh pada kinerja manajerial. Penelitian yang dilakukan oleh Wright (1992) menunjukkan bahwa adanya komitmen karyawan yang tinggi terhadap tugasnya maka akan semakin tinggi pula kinerja yang dihasilkan oleh karyawan tersebut. Berdasarkan teori dan penelitian sebelumnya, maka dapat dirumuskan hipotesis kedua yakni sebagai berikut:

$\mathrm{H}_{2}$ : Komitmen organisasi berpengaruh positif terhadap kinerja manajerial.

Ichniowski et al. (1997) menyatakan kinerja yang tinggi pada dasarnya tergantung pada program pemberian reward jika dikaitkan dengan pekerjaan yang mendukung, yang meliputi penilaian kerja, informasi yang merata. Khim dan Larry (1998) menyatakan peningkatan kinerja dapat dicapai jika praktek TQM digunakan bersama dengan program kinerja yang digunakan sebagai dasar pemberian reward. Penelitian oleh Young et al. (1988) dalam Putro (2010) menunjukan adanya suatu pengaruh interaksi antara TQM dengan menggunakan reward terhadap kinerja, dengan demikian pemberian reward memberikan motivasi bagi karyawan untuk meningkatkan kualitas kinerjanya. Berdasarkan teori dan penelitian sebelumnya, maka dapat dirumuskan hipotesis ketiga yakni sebagai berikut:

$\mathrm{H}_{3}$ : $\quad$ Reward mampu memoderasi pengaruh total quality management pada kinerja manajerial. 
Atmosoeprapto (2000) menyatakan bahwa kinerja ialah fungsi dari kompetensi dan komitmen. Kompetensi adalah fungsi pengetahuan dan keterampilan sedangkan komitmen adalah gabungan dari keyakinan diri seseorang dan motivasi. Sistem reward merupakan salah satu strategi manajemen untuk menciptakan keselarasan antar karyawan agar bisa mencapai tujuan dan sasaran yang telah ditetapkan perusahaan (Walker, 1992). Menurut Trisnaningsih (2007) komitmen adalah sikap dan perilaku yang saling mendorong antara satu dengan yang lain. Manajer yang memiliki komitmen yang baik terhadap organisasinya akan menunjukkan sikap dan perilaku yang positif, berusaha meningkatkan prestasi serta ikut aktif dalam mencapai tujuan organisasi. Komitmen seorang karyawan terhadap organisasinya merupakan wujud dari kesetiaan dan loyalitas seorang karyawan terhadap organisasinya, sehingga karyawan tersebut akan berusaha mewujudkan tujuan organisasi. Berdasarkan teori dan hasil penelitian diatas maka dapat dirumuskan hipotesis keempat yakni sebagai berikut:

$\mathrm{H}_{4}$ : $\quad$ Reward mampu memoderasi pengaruh komitmen organisasi pada kinerja manajerial.

\section{METODE PENELITIAN}

Penelitian ini memakai pendekatan kuantitatif yang berbentuk asosiatif. Menurut Sugiyono (2013:13), pendekatan kuantitatif adalah metode penelitian yang dipakai untuk meneliti populasi atau sampel tertentu yang bertujuan untuk menguji hipotesis yang telah di tetapkan. Desain penelitian ini dapat digambarkan sebagai berikut: 
$\mathrm{H}_{1}(+)$

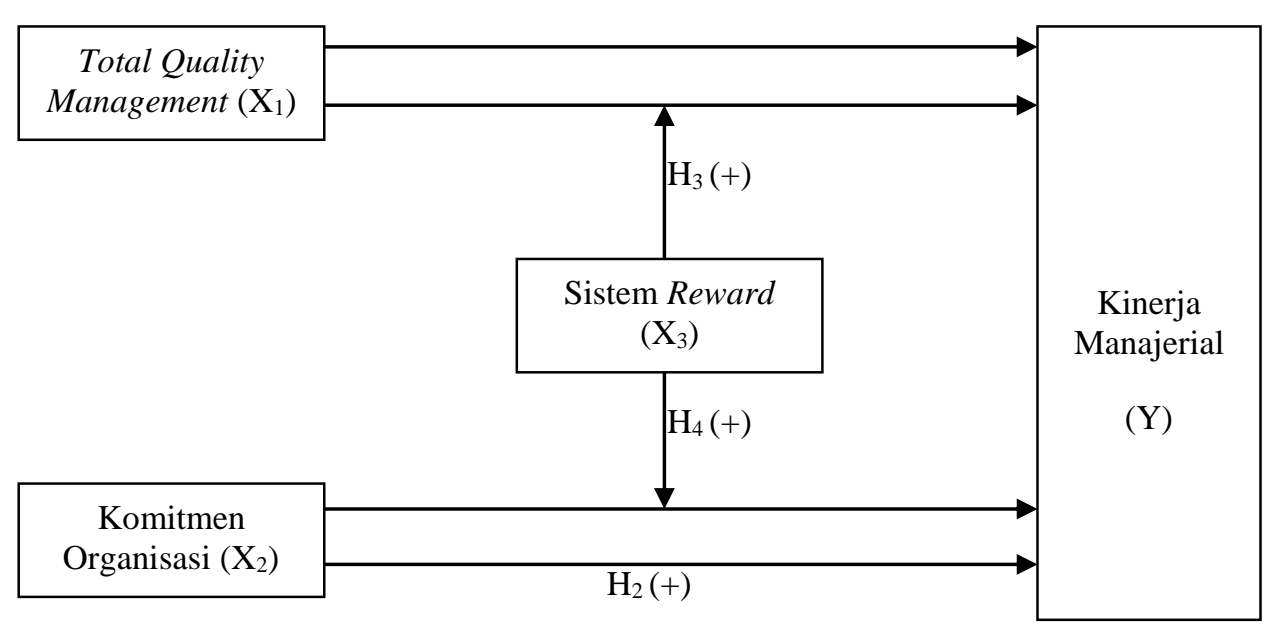

Gambar 1.

Sumber: Data diolah, 2018

Desain Penelitian

Variabel bebas (independent variable) yang digunakan terdiri dari Total Quality Management $\left(\mathrm{X}_{1}\right)$, Komitmen Organisasi $\left(\mathrm{X}_{2}\right)$. Variabel TQM dalam penelitian ini diukur dengan dengan 13 butir pernyataan. Instrumen yang digunakan berupa kuesioner yang dikembangkan oleh Nasution (2005:25).

Komitmen organisasi merupakan suatu usaha melibatkan diri dalam perusahaan dan tidak ada keinginan untuk meninggalkanya (Robbins, 2007). Pengukuran variabel ini dilakukan dengan 4 butir pertanyaan. Instrumen yang digunakan berupa kuesioner yang dikembangkan oleh Puput (2015). Empat indikator Komitmen Organiasi $\left(\mathrm{X}_{2}\right)$ menurut Mowday et al (1982) adalah sebagai berikut: 1) Keinginan untuk tetap bertahan dalam organisasi; 2) Kesamaan dengan nilai-nilai organisasi; 3) Kesamaan dengan tujuan organisasi; 4) Keinginan berusaha keras demi kesuksesan organisasi.

Variabel Moderasi yang digunakan yaitu Reward $\left(\mathrm{X}_{3}\right)$. Sistem penghargaan (reward) yang dimaksudkan dalam penelitian ini adalah pemberian kompensasi 
pada manager di rumah sakit. Variabel ini diukur dengan instrumen yang dipakai oleh Khim dan Larry lalu dikembangkan oleh Simamora (2004). Tujuh indikator Reward $\left(\mathrm{X}_{3}\right)$ adalah sebagai berikut: gaji, insentif, bonus, asuransi, promosi, tunjangan, fasilitas.

Variabel terikat (dependent variable) dalam penelitian ini adalah Kinerja Manajerial (Y). Variabel ini diukur dengan instrumen yang digunakan oleh Narsa dan Yuniawati (2003) yang diadopsi dari Mahoney (1963). Pengukuran variabel ini dilakukan dengan 9 butir pertanyaan. Sembilan indikator komitmen organisasi (Y) adalah sebagai berikut: perencanaan, investigasi, pengkoordinasian, evaluasi, pengawasan, pemilihan staf, negosiasi, perwakilan dan kinerja keseluruhan.

Lokasi atau wilayah penelitian ini adalah pada rumah sakit umum pemerintah dan rumah sakit umum swasta di Kota Denpasar. Peneliti melakukan penelitian pada rumah sakit dikarenakan rumah sakit sebagai tempat pelayanan kesahatan masyarakat senantiasa dituntut untuk memiliki kinerja manajerial yang baik karena akan berdampak pada pelayanan kepada masyarakat. Dipilihnya lokasi penelitian di Kota Denpasar karena Denpasar sebagai ibu kota Provinsi Bali banyak terdapat rumah sakit baik milik pemerintah atau swasta, sehingga memudahkan dalam proses pengumpulan data dan dengan banyaknya rumah sakit di Kota Denpasar ini akan membuat rumah sakit harus terus memperbaiki kinerja manajerialnya.

Penelitian ini menggunakan jenis data kualitatif dan data kuantitatif. Data kualitatif dalam penelitian ini adalah skor dari jawaban kuisioner yang diajukan kepada responden dan daftar banyaknya rumah sakit di Kota Denpasar. Data 
A.A Sagung Istri Devi Parwitasari dan I Wayan Pradnyantha Wirasedana. Pengaruh...

kualitatif dalam penelitian ini adalah daftar nama-nama rumah sakit yang ada di Kota Denpasar. Sumber data dalam penelitian ini meliputin data primer dan data sekunder. Data primer dalam penelitian ini meliputi hasil survei dengan menggunakan kuesioner, dimana respondennya adalah para manajer di rumah sakit. Dalam penelitian ini yang menjadi data sekunder adalah daftar nama dan jumlah rumah sakit di Kota Denpasar.

Populasi dalam penelitian ini adalah seluruh rumah sakit umum pemerintah dan swasta di Kota Denpasar, Provinsi Bali yaitu dengan total 20 rumah sakit umum yang terdiri dari 6 rumah sakit umum pemerintah dan 14 rumah sakit umum swasta. Pemilihan sampel penelitian didasarkan pada metode purposive sampling. Metode pengumpulan data yang digunakan adalah metode survei dengan instrumen kuesioner. Kuesioner yang disebarkan berupa daftar pernyataan tertulis kepada responden mengenai penerapan total quality management, komitmen organisasi, sistem reward, kinerja manajerial. Masing-masing variabel tersebut disiapkan dengan jumlah pernyataan yang berbeda satu dengan yang lainnya. Kuesioner yang digunakan dalam penelitian ini diukur dengan skala likert 5 poin.

Teknik analisis data yang digunakan dalam penelitian ini adalah Moderated Regression Analysis (MRA). Analisis data dalam penelitian ini dilakukan dengan bantuan program SPSS 21.0 for windows. Pada penelitian ini peneliti memilih MRA karena bisa menjelaskan pengaruh varibel pemoderasi dalam memperkuat ataupun memperlemah hubungan independen dan dependen. Rumus uji MRA digambarkan dalam persamaan regresi sebagai berikut. 
$\mathrm{KM}=\beta_{0}+\beta_{1} \mathrm{TQM}+\beta_{2} \mathrm{KO}+\beta_{3} \mathrm{SR}+\beta_{4}[\mathrm{TQM} * \mathrm{SR}]+\beta_{5}[\mathrm{KO} * \mathrm{SR}]+\varepsilon$

Keterangan:
KM
: Kinerja Manajeral
TQM : Penerapan Total Quality Management
KO : Komimen Organisasi
SR : Sistem Reward
$\beta_{0} \quad$ : Konstanta
$\beta_{1}-\beta_{5} \quad$ : Koefisien regresi
[TQM*SR] : Interaksi antara penerapan total quality management dengan sistem reward
[KO*SR] : Interaksi antara komitmen organisasi dengan sistem reward
$\varepsilon \quad:$ Standard error of estimate

\section{HASIL DAN PEMBAHASAN}

Statistik deskriptif disajikan untuk memberikan informasi mengenai karakteristik variabel-variabel penelitian yang terdiri dari jumlah amatan, nilai minimum, nilai rata-rata, dan standar deviasi (simpangan baku) dengan $\mathrm{N}$ adalah banyaknya responden penelitian. Hasil analisis statistik deskriptif dapat dilihat pada Tabel 1. berikut.

Tabel 1.

Hasil Statistik Deskriptif

\begin{tabular}{lccccc}
\hline \multicolumn{1}{c}{ Variabel } & N & Min. & Maks. & Rata-rata & Simpangan Baku \\
\hline Total Quality Management $\left(\mathrm{X}_{1}\right)$ & 55 & 2,85 & 4,85 & 3,7930 & 0,45649 \\
Komitmen Organisasi $\left(\mathrm{X}_{2}\right)$ & 55 & 2,40 & 4,80 & 3,6400 & 0,56490 \\
Sistem Reward $\left(\mathrm{X}_{3}\right)$ & 55 & 2,83 & 4,83 & 3,9303 & 0,39112 \\
Kinerja Manajerial $(\mathrm{Y})$ & 55 & 3,56 & 4,78 & 4,2202 & 0,31390 \\
\hline
\end{tabular}
Sumber: Data diolah, 2018

Tabel 1. menunjukkan bahwa variabel total quality management $\left(\mathrm{X}_{1}\right)$ dengan nilai rata-rata sebesar 3,7930, nilai minimum 2,85 dan nilai maksimum 4,85. Hal tersebut menunjukkan adanya penerapan total quality management pada kinerja manajer pada rumah sakit di Kota Denpasar, yang artinya sebagian besar responden cenderung menjawab setuju pada 13 item pernyataan dalam variabel total quality management. Variabel komitmen organisasi $\left(\mathrm{X}_{2}\right)$ memiliki nilai rata- 
A.A Sagung Istri Devi Parwitasari dan I Wayan Pradnyantha Wirasedana. Pengaruh...

rata sebesar 3,6400 dengan nilai minimum 2,40 dan nilai maksimum 4,80. Hal ini menunjukkan bahwa manajer di rumah sakit di Kota Denpasar memiliki komitmen organisasi yang tinggi. Hal tersebut juga dapat dilihat dari nilai rata-rata lebih mendekati nilai maksimal, yang artinya sebagian besar responden cenderung menjawab setuju pada 5 item pernyataan dalam variabel komitmen organisasi.

Variabel Sistem Reward $\left(\mathrm{X}_{3}\right)$ menunjukkan rata-rata sebesar 3,9303 dengan nilai minimum 2,83 dan nilai maksimum 4,83 . Hal tersebut berarti bahwa rumah sakit sudah menerapkan reward sehingga kinerja manager pada rumah sakit di Kota Denpasar sudah terlaksana dengan baik. Hal tersebut juga dapat dilihat dari nilai rata-rata lebih mendekati nilai maksimal, yang artinya sebagian besar responden cenderung menjawab setuju pada 12 item pernyataan dalam variabel sistem reward. Variabel kinerja manajerial (Y) menunjukkan rata-rata sebesar 4,2202 dengan nilai minimum 3,56 dan nilai maksimum 4,78. Hal tersebut berarti bahwa kinerja manajerial pada rumah sakit di Kota Denpasar sudah baik. Hal tersebut juga dapat dilihat dari nilai rata-rata lebih mendekati nilai maksimal, yang artinya sebagian besar responden cenderung menjawab setuju pada 5 item pernyataan dalam variabel kinerja manajerial.

Pengujian validitas pada penelitian ini diperoleh nilai pearson correlation bernilai di atas 0,30 yang menandakan bahwa instrumen penelitian yang digunakan telah valid dan dapat digunakan. Uji reliabilitas dilakukan terhadap instrumen dengan melihat nilai koefisien cronbach's alpha. Variabel dapat dikatakan reliabel jika memiliki nilai Cronbach's Alpha > 0,60 (Ghozali, 2011:43). Hasil olah data untuk uji reliabilitas pada penelitian ini menunjukkan bahwa seluruh instrumen 
penelitian yaitu total quality management, komitmen orgnisasi, sistem reward dan kinerja manajerial memiliki koefisien Cronbach's Alpha lebih besar dari 0,60 sehingga bisa dinyatakan bahwa pernyataan pada kuesioner tersebut reliabel.

Uji normalitas bertujuan untuk mengetahui apakah residual dari model regresi yang dibuat berdistribusi normal atau tidak. Hasil olah data untuk uji normalitas pada penelitian ini menunjukkan bahwa nilai Kolmogorov Sminarnov (K-S) sebesar 0,645, sedangkan nilai Asymp. Sig. (2-tailed) sebesar 0,799. Hasil tersebut mengindikasikan bahwa model persamaan regresi tersebut berdistribusi normal karena nilai Asymp. Sig. (2-tailed) 0,799 lebih besar dari nilai alpha 0,05.

Model regresi yang baik seharusnya bebas dari heteroskedastisitas atau yang disebut dengan homoskedastisitas. Uji glejser dilakukan dengan meregresikan nilai absolut dengan variabel bebasnya. Apabila signifikan t hasil meregresi nilai absolute residual terhadap variabel bebas lebih dari 0,05 maka model regresi bebas heteroskedastisitas. Hasil olah data untuk uji heteroskedastisitas pada penelitian ini menunjukkan bahwa nilai sig. masing-masing variabel berada diatas 0,05 sehingga model regresi yang digunakan bebas heteroskedastisitas. Berdasarkan hasil uji normalitas, dan uji heteroskedastisitas yang diperoleh maka dapat dinyatakan model regresi penelitian ini lolos uji asumsi klasik.

Dalam penelitian ini, untuk menganalisis data digunakan metode analisis regresi moderasi. Analisis regresi moderasi digunakan untuk mengetahui dan menunjukkan status dan pengaruh dari variabel moderasi sistem reward terhadap kinerja manajerial. 
Tabel 2.

Hasil Moderated Regression Analysis (MRA)

\begin{tabular}{|c|c|c|c|c|c|}
\hline \multirow[t]{2}{*}{ Model } & \multicolumn{2}{|c|}{ Unstandardized Coefficients } & \multirow{2}{*}{$\begin{array}{c}\begin{array}{c}\text { Standardized } \\
\text { Coefficients }\end{array} \\
\text { Beta }\end{array}$} & \multirow[t]{2}{*}{$\mathbf{t}$} & \multirow[t]{2}{*}{ Sig. } \\
\hline & $\mathbf{B}$ & Std. Error & & & \\
\hline $\begin{array}{ll}1 & \text { (Constant) }\end{array}$ & 0,002 & 0,066 & & 0,027 & 0,979 \\
\hline TQM & 0,244 & 0,119 & 0,244 & 2,057 & 0,045 \\
\hline KO & 0,230 & 0,108 & 0,230 & 2,132 & 0,038 \\
\hline SR & 0,235 & 0,097 & 0,235 & 2,414 & 0,020 \\
\hline $\mathrm{TQM} * \mathrm{SR}$ & 0,215 & 0,080 & 0,237 & 2,685 & 0,010 \\
\hline $\mathrm{KO} * \mathrm{SR}$ & 0,196 & 0,079 & 0,178 & 2,474 & 0,017 \\
\hline F hitung & $: 35,356$ & & & & \\
\hline Signifikansi F & $: 0,000$ & & & & \\
\hline $\mathrm{R}$ Square & $: 0,783$ & & & & \\
\hline Adjusted R Square & $: \quad 0,761$ & & & & \\
\hline
\end{tabular}

Berdasarkan hasil analisis pada Tabel 2. menunjukkan nilai konstanta sebesar 0,002 memiliki arti apabila total quality management $\left(\mathrm{X}_{1}\right)$, komitmen organisasi $\left(\mathrm{X}_{2}\right)$, sistem reward $\left(\mathrm{X}_{3}\right)$ konstan, maka nilai kinerja manajerial (Y) sebesar 0,002 satuan. Nilai koefisien regresi total quality management (TQM) memiliki tanda positif yang memiliki arti jika penerapan total quality management tinggi maka terdapat peningkatan kinerja manajerial (Y). Nilai koefisien regresi komitmen organisasi (KO) memiliki tanda positif yang memiliki arti jika komitmen organisasi tinggi maka terdapat peningkatan kinerja manajerial (Y). Nilai koefisien regresi sistem reward (SR) memiliki tanda positif yang memiliki arti jika sistem reward (SR) tinggi makan terdapat peningkatan kinerja manajerial (Y). Nilai koefisien regresi interaksi TQM*SR memiliki tanda positif mengindikasikan bahwa apabila hubungan total quality management dengan sistem reward tinggi, maka kinerja manajerial akan meningkat. Nilai koefisien regresi interaksi KM*SR memiliki tanda positif mengindikasikan bahwa apabila hubungan komitmen organisasi dengan sistem reward tinggi, maka kinerja manajerial akan meningkat. 
ISSN: 2302-8556

Pada pengujian ini dihitung besarnya koefisien determinasi $\left(\mathrm{R}^{2}\right)$ yang merupakan koefisien yang menunjukkan besarnya persentase pengaruh variabel independen terhadap variabel dependen. Berdasarkan hasil analisis data diperoleh nilai Adjusted R-Square sebesar 0,761. Hal ini berarti bahwa sebesar 0,761 atau $76,1 \%$ variasi kinerja manajerial mampu dijelaskan oleh variabel total quality management, komitmen organisasi serta sistem reward sebagai pemoderasi, sedangkan sisanya sebesar 23,9 persen dipengaruhi oleh variabel lain yang tidak masuk dalam model.

Uji F digunakan untuk melihat kelayakan model penelitian. Uji statistik F pada dasarnya bertujuan untuk melihat apakah semua variabel independen atau bebas yang dimaksud dalam model mempunyai pengaruh secara serempak terhadap variabel dependen atau terikat. Berdasarkan model yang telah dianalisis, diketahui

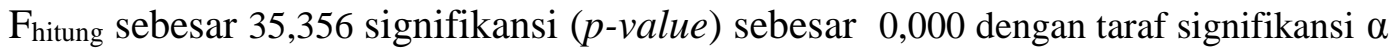
$=5 \%$, hal ini mengandung arti bahwa seluruh variabel mampu memprediksi atau menjelaskan fenomena kinerja manajerial pada rumah sakit di Kota Denpasar dan model regresi yang digunakan dianggap layak uji.

Berdasarkan Tabel 2. diperoleh koefisien total quality management $\left(\beta_{1}\right)$ sebesar 0,244 dengan nilai signifikansi 0,045 lebih kecil dari $\alpha(0,045<0,05)$. Hasil tersebut berarti bahwa penerapan total quality management berpengaruh positif dan signifikan pada kinerja manajerial. Hal ini berarti hipotesis pertama $\left(\mathrm{H}_{1}\right)$ diterima, yaitu penerapan TQM berpengaruh positif terhadap kinerja manajerial. Jawaban responden menunjukkan bahwa penerapan total quality management pada rumah sakit di Kota Denpasar cenderung tinggi, karena dengan adanya TQM, kinerja 
A.A Sagung Istri Devi Parwitasari dan I Wayan Pradnyantha Wirasedana. Pengaruh...

manajerial juga akan meningkat, sebab dalam penerapan TQM manajer memiliki kendali pada kualitas jasa yang akan dihasilkan. Kualitas jasa yang tinggi akan bias mempengaruhi kepuasan pelanggan dan dapat meningkatkan penjualan sehingga kinerja perusahaan dapat dikatakan meningkat. Hasil penelitian ini sejalan dengan penelitian oleh Supratiningrum dan Zulaikha (2003), Mardiah dan Listianingsih (2005), Bekka (2007) yang juga memperoleh hasil bahwa penerapan TQM memiliki pengaruh positif pada kinerja manajerial.

Berdasarkan Tabel 2. diperoleh koefisien komitmen organisasi $\left(\beta_{2}\right)$ sebesar 0,230 dengan nilai signifikansi 0,038 lebih kecil dari $\alpha(0,038>0,05)$. Hasil tersebut berarti bahwa komitmen organisasi berpengaruh positif dan signifikan pada kinerja manajerial. Hal ini berarti hipotesis kedua $\left(\mathrm{H}_{2}\right)$ diterima yaitu komitmen organisasi berpengaruh positif terhadap kinerja manajerial. Jawaban responden menunjukkan bahwa komitmen organisasi manajer di rumah sakit se-Kota Denpasar cenderung tinggi, karena para manajer cenderung mempunyai nilai-nilai yang sama dengan rumah sakit tempat mereka bekerja, selain itu para manajer juga cenderung merasa bangga menjadi bagian dari perusahaan khusunya rumah sakit. Komitmen organisasi yang tinggi akan meningkatkan kepercayaan diri, loyalitas dan inividu akhirnya merasa bertanggung jawab dan ikut merasa memiliki orgnaisasi tersebut, sehingga akan berdampak pada peningkatan kinerja. Hasil penelitian ini konsisten dengan penelitian yang dilakukan oleh Rian (2012), Dika (2016) yang menyatakan komitmen organisasi berpengaruh positif pada kinerja manajerial.

Berdasarkan Tabel 2. diperoleh nilai koefisien interaksi $\left(\beta_{4}\right)$ antara total quality management dan sistem reward sebesar 0,237 dengan nilai signifikansi 
ISSN: 2302-8556

sebesar 0,010 lebih kecil dari $\alpha(0,010>0,05)$. Nilai koefisien yang signifikan pada variabel bebas dan nilai koefisien yang signifikan pada variabel interaksinya menandakan bahwa status dari sistem reward adalah quasi moderasi. Selain itu, karena tanda dari koefisien interaksinya positif maka ini berarti sistem reward mampu memoderasi (memperkuat) hubungan antara total quality management terhadap kinerja manajerial, sehingga $\mathrm{H}_{3}$ diterima, yaitu reward mampu memoderasi (memperkuat) pengaruh total quality management pada kinerja manajerial. Jawaban dari responden terkait item pernyataan pada sistem reward cenderung memberikan jawaban setuju yang artinya rata-rata responden termotivasi melakukan sistem TQM ini karena telah mendapat penghargaan yang cukup dari perusahaanya. Sistem reward yang cukup mendorong terjadinya kesuksesan penerapan TQM, karena ketika manajer merasa sudah mendapatkan reward memadai maka manajer akan terus berusaha untuk meningkatkan perbaikan dan kualitas yang sejalan dengan konsep TQM. Hasil penelitian ini sejalan dengan penelitian oleh Suprantiningrum dan Zulaikha (2003), Ittner dan Larcker (1995), yang menyatakan bahwa semakin tinggi sistem reward yang diberikan perusahaan maka semakin tinggi pula kinerja yang dihasilkan oleh manajemen perusahaan itu.

Berdasarkan Tabel 2. diperoleh nilai koefisien interaksi $\left(\beta_{5}\right)$ antara komitmen organisasi dan sistem reward sebesar 0,178 dengan nilai signifikansi sebesar 0,017 lebih kecil dari $\alpha(0,017<0,05)$. Nilai koefisien yang signifikan pada variabel bebas dan nilai koefisien yang signifikan pada variabel interaksinya menandakan bahwa status dari sistem reward adalah quasi moderasi. Selain itu, karena tanda dari koefisien interaksinya positif maka ini berarti sistem reward 
A.A Sagung Istri Devi Parwitasari dan I Wayan Pradnyantha Wirasedana. Pengaruh...

mampu memoderasi (memperkuat) hubungan antara komitmen organisasi terhadap kinerja manajerial, sehingga hipotesis keempat $\left(\mathrm{H}_{4}\right)$ diterima, yaitu reward mampu memoderasi (memperkuat) pengaruh komitmen organisasi pada kinerja manajerial. Jawaban dari responden terkait item pernyataan pada sistem reward cenderung memberikan jawaban setuju yang artinya rata-rata responden memiliki komitmen organisasi yang tinggi karena diperusahaannya sudah menerapkan sistem reward yang cukup dari perusahaanya.

Sistem reward yang cukup mendorong meningkatnya komitmen organisasi, karena ketika manajer sudah mendaptkan reward yang cukup atas hasil kerja mereka, para manajer akan memiliki komitmen organisasi yang tinggi, jika manajer mempunyai komitmen organisasi yang tinggi maka manajer akan mempunya sikap dan perilaku yang positif terhadap perusahaanya, manajer akan berusaha meningkatkan prestasi, memiliki keyakinan untuk mencapai tujuan organisasi sehingga hasilnya kinerja manager akan meningkat. Hal ini sesuai dengan jawaban responden terkait kinerja manajerial yang menyatakan manajer yakin bahwa kinerja pada divisnya terlaksana dengan baik. Hasil penelitian ini mendukung penelitian Endang (2015), Dika (2016), Mardiyati (2014) yang menyatakan bahwa semakin tinggi sistem reward yang diberikan perusahaan maka semakin tinggi pula kinerja yang dihasilkan oleh manajemen perusahaan tersebut.

\section{SIMPULAN}

Berdasarkan hasil penelitian yang diperoleh serta pembahasan seperti yang telah diuraikan, maka dapat disimpulkan bahwa: 1) Total quality management berpengaruh positif signifikan pada kinerja manajerial; 2) Komitmen organisasi 
ISSN: 2302-8556

berpengaruh positif signifikan pada kinerja manajerial; 3) Sistem reward merupakan quasi moderasi yang mampu memoderasi secara positif (memperkuat) pengaruh total quality management terhadap kinerja manajerial; 4) Sistem reward merupakan quasi moderasi yang mampu memoderasi secara positif (memperkuat) pengaruh komitmen organisasi terhadap kinerja manajerial.

Berdasarkan hasil penelitian dan simpulan, maka saran yang dapat diberikan bagi penelitian selanjutnya agar menguji pengaruh moderasi dengan menggunakan variabel lain karena berdasarkan nilai adjusted $R$-Square tersisa sebesar 23,9\% yang masih dipengaruhi oleh variabel lain yang tidak dimasukkan dalam model seperti budaya organisasi. Selain itu sampel yang digunakan dalam penelitian ini hanya terbatas pada rumah sakit di Kota Denpasar, maka perlu dilakukan penelitian kembali pada jenis perusahaan yang berbeda yaitu manufaktur, perbankan pada lokasi yang sama atau perusahaan sejenis pada lokasi yang berbeda.

\section{REFERENSI}

Adang, Y. S. P., \& Hernawati, E. 2013. Pengaruh Sistem Pengukuran Kinerja, Total Quality Management dan Sistem Penghargaan Terhadap Kinerja Manajerial. Jurnal Universitas Pembangunan Nasional Veteran Jakarta.

Ahire, S. L., \& Dreyfus, P. 2000. The Impact of Design Management and Process Management on Quality: An Empirical Investigation. Journal of Operations Management, 18, pp: 549-575.

Angelina, Rian. 2012. Effect Of Total Quality Management, Reward System And Organization Commitment To Managerial Performance In Hospital Pekanbaru. Jurnal FE Universitas Riau.

Badri, M. A., Davis, D., dan Davis, D. 1995. A study of measuring the critical factors of quality manageament. International Journal of Quality \& Reliability Management, 12(2), pp:36-53. 
Bekka, Muh. Jaffar. 2007. Pengaruh Total Quality Management (TQM) Terhadap Kinerja Manajerial Pada Industri Kayu Olahan di Kota Palu. Jurnal Transaksi,4(2).

Choi, T. Y., dan Eboch, K. 1998. The TQM Paradox: Relations among TQM Practices, Plant Performance, and Customer Satisfaction. Journal of Operations Management, 17(1), pp:59-75.

Chong, V. K., dan Rundus, M. J. 2004. Total quality management, market competition and organizational performance. British Accounting Review, 36,pp:155-172

Dahar, Dila Liliyatri. 2012. Gaya Kepemimpinan sebagai Varibabel Moderating dalam Penerapan Total Quality Management terhadap Kinerja Manajerial pada PT. Samsung Elektronik Indonesia. Jurnal FE UPN Veteran Jatim.

Dewi, I.R. 2013. Pengaruh Penerapan Total Quality Management (TQM), Sistem Pengukuran Kinerja dan Sistem Penghargaan ( Reward) Terhadap Kinerja Manajerial Studi Empiris pada Hotel di Kota Padang dan Bukittinggi. Jurnal Universitas Negeri Padang,h:1-24.

Demirbag, M., Tatoglu, E., Tekinkus, M., \& Zaim, S. 2006. An Analysis of the Relationship between TQM Implementation and Organizational Performance: Evidence from Turkish SMEs. Journal of Manufacturing Technology Management, 17(6), pp: 829-847.

Douglas, T. J., dan Judge, W. Q. 2001. Total quality management implementation and competitive advantage: The role of structural control and exploration. Academy of Management Journal, 44(1), pp: 158-169.

Easton, G.S dan Jarrel, S.L. 1998. The Effects of Total Quality Management on Coorporate Performance: An Emprical Investigation. Journal of Business, 71(2), pp: 253-307.

Ghozali, Imam. 2016. Aplikasi Analisis Multivariate dengan Program SPSS. Semarang : Badan Penerbit Universitas Diponegoro

Ichniowski, C., K. Shaw and G. Prennushi. 1994. The Effect of Human Resource Management Practices on Productivity : A Study of Finishing Lines. American Economic Review.

Ittner, C. D., \& Larcker, D. F. 1996. Total Quality Management and the Choice of Information and Reward Systems. Journal of Accounting Research, 33, pp: 134. 
Khan, J. H. 2003. Impact of total quality management on productivity. The TQM Magazine, 15(6), pp: 374-380.

Kaynak, H. 2003. The relationship between total quality management practices and their effects on firm performance. Journal of Operations Management, 21(4), pp: 405-435.

Kumentas, C. N. 2013. Pengaruh TQM, Sistem Penghargaan Dan Sistem Pengukuran Kinerja Terhadap Kinerja Manajerial Pada PT. Air Manado. Jurnal Riset Ekonomi, Manajemen, Bisnis Dan Akuntansi, 1(3).

Lestari, R. D. H. .2015. Pengaruh Total Quality Management, Sistem Pengukuran Kinerja dan Sistem Penghargaan Terhadap Kinerja Manajerial (Studi Empiris Pada RSUD RAA Soewondo Pati). Jurnal Universitas Muhhamadiah.

Lloréns Montes, F. J., Verdú Jover, A., \& Miguel Molina Fernández, L. 2003. Factors affecting the relationship between total quality management and organizational performance. International Journal of Quality \& Reliability Management, 20(2), pp:189-209.

Made, N., Apsari, S., dan Sujana, I. K. 2013. Pengaruh Budgetary Goal Characteristics Terhadap Kinerja Manajerial Dengan Motivasi Dan Komitmen Organisasi Sebagai Variabel Moderating. Jurnal Akuntansi Universitas Udayana, 31

Manuele, L. E. 1995. The impact of the "total quality management" movement on management accounting. Journal of Accounting Education, 13(1), pp: 111118

Mardiyah, A. A., dan Listianingsih. 2005. Pengaruh Sistem Pengukuran Kinerja, Sistem Reward, Dan Profit Center Terhadap Hubungan Antara Total Quality Management Dengan Kinerja Manajerial. SNA VIII Solo, (September), h: 1516.

Mosadeghrad, A. M. 2006. The impact of organizational culture on the successful implementation of total quality management. The TQM Magazine, 18(6), pp: 606-625.

Mowday, R., Steers, R. dan Porter, L. 1979 . The Measurement of Organizatlonal Commitment. Journal of Vocational Behavior, pp: 224-247.

Narsa I Made, dan Rani Dwi Yuniawati. 2003. Pengaruh Interaksi Antara Total Quality Management Dengan Sistem Pengukuran Kinerja Dan Sistem Penghargaan Terhadap Kinerja Manajerial Studi Empiris pada PT. Telkom Divre V Surabaya. Jurnal Akuntansi Dan Keuangan, 5,h: 18-34. 
A.A Sagung Istri Devi Parwitasari dan I Wayan Pradnyantha Wirasedana. Pengaruh...

Nastiti Mintje. 2013. Pengaruh TQM,Sistem Penghargaan Dan Sistem Pengkuran Kinerja Terhadap Kinerja Manajerial Pada PT.Air Manado. Jurnal EMBA, 1(3),h: 52-62.

Nasution, M. Nur. 2005. Total Quality Management. Jakarta: PT. Gramedia Pustaka Utama.

Prof, A., \& Karahan, M. 2012. The Determination of the Effect Level on Employee Performance of TQM Practices with Artificial Neural Networks: A Case Study on Manufacturing Industry Enterprises in Turkey. Journal of Business, 3(7), pp: 133-142.

Reed, R., Lemak, D. J., \& Montgomery, J. C. 1996. Beyond process: TQM content and firm performance. Academy of Management Review, 21(1), pp: 173-202.

Tjiptono, Fandy dan Diana, Anastasia. 2003. TQM ( Total Quality Management). Yogyakarta. Andi Offset. 